\title{
Achievement training- A re-assessment of the technique and its impact on the development of supervisory and managerial talent in Southern Africa
}

\author{
Martin E. Nasser \\ School of Business Leadership, University of South Africa, Pretoria
}

Against a scenario of an ever-increasing demand for a greater number of managers and supervisors - particularly Black talent - into the Southern African economies, this paper explores the real contribution Achievement Training has been making over the past four years. Specifically its contribution to developing managerial and supervisory talent is explored and its concomitant contribution to alleviate the critical 1:42 manager to worker ratio currently being experienced on this sub-continent

The Nasser Achievement Training Process has its origins in the work of Harvard Professor David McClelland's three-band theory. The develop ment of this process is examined from both a construct and pedagogics point of view for purposes of critically reviewing its nature and impact.

A longitudinal analysis of the results of some 2985 prospective managers/supervisors who were exposed to the Achievement Training process reveals a number of very positive trends. The results indicate significant tevels of improvement in performance on-the-job as adjudged by the immediate line managers on 10 work-related managerial supervisory dimensions.

What is even more significant is that some $60 \%$ of the participants received promotions of between 1 and 4 levels during the observation period - the majority being Black. These results indicate the powertul nature of this Achievement Training process.

The author argues that despite the significance of these results, this training process needs to be organic by nature. A restructuring of the contents has been proposed in order to equip even-better the latent manageria! talent within the organization. Also the critical role of a well-trained Mentor has come into sharp focus as being a major facilitator in growing this managerial and supervisory talent at the fastest possible pace

S. Afr. J. Bus. Mgmt. 1984, 15:105- 108

Teen die agtergrond van 'n steeds-toenemende behoefte aan 'n groter aantal bestuurders en toesighouers - veral swart talent - vir Suid-Afrikaanse maatskappye, ondersoek hierdie artikel die bydrae van Prestasie-Opleiding oor die afgelope aantal jare. Meer spesifiek word die bydrae van Prestasie-Opleiding t.o.v. bestuurs- en toesig-potensiaal ondersoek en daarmee saam die bydrae wat dit gemaak het om die kritieke 1:42 bestuurder-tot-werker-ratio wat tans op die subkontinent ondervind word, te verlig.

Die Nasser Prestasie-Opleidingsproses is op die werk van Harvard professor David McClelland se drie-band teorie gebaseer. Die ontwikke ling van die proses word ondersoek uit beide 'n teoretiese- en 'n pedagogiese oogpunt, met doelstelling om die aard en bydrae daarvan krities te oorweeg

'n Langtermyn-studie van die bevindinge van ongeveer 2985 voornemende bestuurders/toesighouers wat aan die Prestasie-Opleiding blootgestel was, toon 'n baie positiewe neiging. Die bevindinge toon 'n beduidende verbetering in werksprestasie (soos deur onmiddellike hoofde waargeneem). Meer beduidend was die feit dat $69 \%$ van die deelnemers verhogings tussen 1 tot 4 vlakke, tydens die opvolgings fases getoon het - meesal binne swart geledere. Hierdie resultate toon die sterk invloed van die Prestasie-Opleidingsproses.

Die skrywer reken dat, ten spyte van die beduidendheid van die resultate, die opleidingsproses organies van aard moet wees. ' $n$ Herkonstruering van die inhoud word voorgestel, met die doel om die bestuurspotensiaal selfs beter te ontwikkel. Verder nog, word die kritiese rol van die MENTOR onderstreep as 'n uiters belangrike faset in die ontwikkeling van bestuurs. en toesighoudende potensiaal, teen die vinnigste tempo.

S.-Afr. Tydskr. Bedryfsl. 1984, 15:105-108

Martin E. Nasser

School of Business Leadership, University of South Africa,

P.O. Box 392, Pretoria 0001, Republic of South Africa

Accepted January 1984

\section{Introduction}

One of the most crucial challenges facing the nations of Southern Africa to the 1990s is the need for developing an adequate quantity and quality of managerial and supervisory material - particularly Black material - to run, sustain and grow the business and governmental processes which underpin the economic growth of this sub-continent.

That business in South Africa is more than aware of this need is apparent from the visible effort presently being exerted in this direction and is further reflected in the findings of the report on 'The Manpower Analysis for the PWV Area to the Period 1984' UNISA (1980). A preliminary analysis of its findings indicate a five-fold increase in effort in this regard during the next five years. That business has not been unduly excited by the results obtained so far is more than apparent from the findings of the studies by Nasser, Motsepe and Lenamile (1980), Nasser and Tabane (1981) and Hofmeyr (1982).

Typically management has been less than satisfied with the results achieved to date. Too little new supervisory and managerial talent has emerged from the diversity of training and developmental efforts - particularly among Blacks and this has only tended to cause extra strain on an already over-extended span of control.

As is apparent from Figure 1, the manager in South Africa (and the same applies to other Southern African countries) is grossly overloaded, and this only serves to aggravate the existing problems inherent to the already overtaxed workplace.

It was in looking at these complexities and the accompanying poor track record for developing managers and supervisors - particularly Black managers, - that I became interested in trying to determine what specific solutions could be found for this specific problem.

While recognizing the impact of variables such as corporate culture, attitudes, educational inadequacies, psychological distance from the free-enterprise system and socio-political constraints, I was more concerned about the role and nature of personal motivation patterns in causing managerial growth.

The work of Harvard professor David McClelland became a natural point of focus as the search for a solution continued.

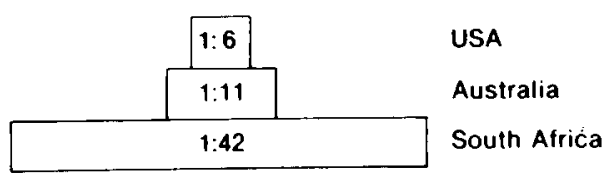

Figure 1 An international comparison of manager to worker ratios (Sadie, 1979) 
McClelland's (1958) three-band theory focuses on the needs patterns of individuals and hence reflects the accompanying motivation and behaviour patterns that accompany these.

\section{The threo-band theory}

McClelland's (1958) three-band theory classifies the needs patterns of individuals as:

(a) need for Affiliation - $\mathrm{n}$ Aff;

(b) need for Achievement - $\mathrm{n}$ Ach;

(c) need for Power - n Pow.

In attempting to define these needs in relation to the specific issue at stake the concentration will be on the need for Affiliation (n Aff) and the need for Achievement (n Ach) and those elements which are most relevant to the free-enterprise system specified for this system.

\section{n Aff characteristics:}

- group minded,

- dependent,

- high on support,

- goals dictated by others,

- follower behaviour,

- evasion of obstacles,

- lacks tenacity.

\section{n Ach characteristics:}

- individualist,

- independent,

- self-starter,

- moderate risk-taker,

- problem resolver,

- high on decision-making,

- leader behaviour,

- high tenacity.

The research on the incidence of these needs and their significance for economic growth is very substantial. The more eminent works of McClelland (1958, 1961, 1973, 1975); Rosen (1959); Atkinson (1966); Winter (1973) and Willers (1983) point out two major features of this need structure:

(a) the dominant need which emerges in a given nation is a product of the socio-cultural make-up of that nation e.g., $\mathrm{n}$ Ach is dominant in northern Europe;

(b) there is a direct significant relationship between the incidence of $n$ Ach in a nation and the economic growth of that nation. The higher the incidence of $n$ Ach, the more economically prosperous is that nation likely to be.

By examining the characteristics of $n$ Ach, it is more than apparent that good management/supervision and $\mathrm{n}$ Ach go hand in hand. From the abovementioned research it would also appear that the economically more prosperous nations have averaged a $15 \%$ n Ach: $85 \%$ n Aff mix (i.e. $15 \%$ leaders/ innovators and $85 \%$ followers). Broad observation by the author Nasser (1978) and others; Nasser, Lenamile and Tabane (1980), Tabane (1981), Thopane (1982) has indicated that the picture for the South African population is approximately 3\% $\mathrm{n}$ Ach and $\mathbf{9 7 \%} \mathrm{n}$ Aff. Hence, there is a major bias towards $\mathrm{n}$ Aff with only a very small incidence of $\mathrm{n}$ Ach. The reasons for this skewed distribution is the subject for another discussion. But the implications for developing core managerial material are more than obvious. There are far fewer natural managers, leaders, entrepreneurs and innovators per population in Southern Africa - when compared with American and European norms, - than is required for the dynamic sus- tenance and growth of its economic systems.

Clearly the need for Achievement - n Ach - has to be activated and developed in selected employees if we intend generating the volume and quality of managers/supervisors required for prosperity in this sub-continent.

\section{The design of the original $\mathbf{n}$ Ach programme}

The 'Achievement Training Programme' devised by Nasser, Tabane and Dias (1978) to cause the shift towards n Ach makes use of the experiential learning process in combination with Skinner's (1972) 'Operant Conditioning', Herzberg's (1968) 'Job Enrichment', Sorcher's (1971) 'Behaviour Modeling,' Humbles (1974), 'Management by Objectives', and Zaleznik's (1977) 'Minimum vs Maximum Man'.

The original design (Nasser, 1978) which was a hybridized version of McClelland's (1961) original thinking, contained among others the following major elements:

- Understanding Motivation,

- Orientation to Achievement Motivation,

- The Economic System,

- Resource Management,

- Planning Process,

- The Free-Enterprise system,

- Creativity and Initiative,

- Individualism and Independence,

- Leadership,

- Managing Interpersonal Relationships,

- Self-Management,

- Career Growth,

- The Pygmalion Effect.

The weighting in emphasis was essentially towards selfmotivation and self-growth. The student was taught to explore how an increase in achievement motivation could assist in this process.

Based on a longitudinal design spread over some 5 months with a classroom contact of 5 hours every second week, the 12 modules are ideally led by an experienced process consultant. (See Figure 2).

The emphasis is on getting individuals to look at the options and opportunities which achievement motivated thinking has to offer. In this respect an opening of another Johari Window (1977 Annual Handbook for Facilitators) provides the individual with an optional motivation pattern, which, if accepted, in its own right brings specific rewards for the individual.

The process is relatively simple, but effective. The classroom process essentially consists of using the experiential learning method to teach the individual the concepts and generate appropriate attitudes towards those elements outlined earlier. Divided into syndicates, the trainees leave the classroom for their job situations and within the intervening two weeks will complete a syndicate assignment with the major objective of ensuring application of the theoretical back into the job en-

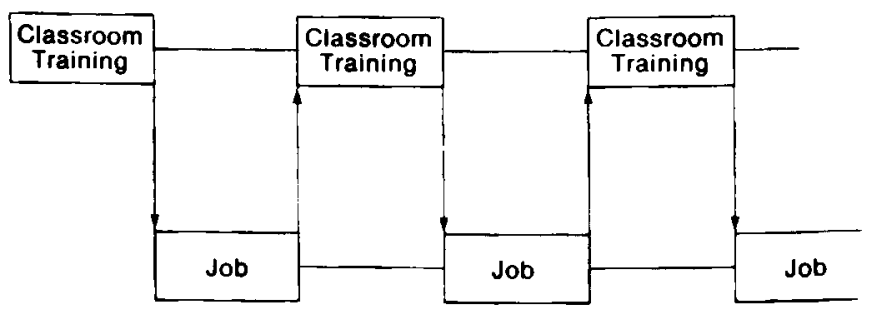

Figure 2 The interactive training design 
vironment. Such syndicate assignments are then presented at the next classroom session.

Overseeing the whole process are the designated Mentors - preferably the first-line managers. The impact of these mentors has been substantial and according to Nasser and Buitendag (1983) provide an important additional dimension for the individual's development.

This whole process lasts approximately five months and is totally interactive in nature.

\section{Results from the original programme}

Since the inception of the Achievement Programme in 1978, some 2985 prospective managers/supervisors - 1964 being Black - from 71 organizations - representing every sector from Mining to Banking - have been involved in this training process. A careful screening procedure using the Rotter IE Scale - and Ghisellis' SDQ - was utilized in identifying those candidates most likely to benefit from this training process.

The impact of the training was measured both

(a) psychometrically for a shift in $\mathrm{n}$ Ach and self-esteem, and

(b) by immediate-boss ratings on the following dimensions;

- Self-sufficiency,

- Attitude,

- Creativity and Problem Solving,

- Decision-making,

- Time keeping,

- Work Accuracy,

- Work Rate,

- Productivity,

- Handling of interpersonal relationships,

- Control of subordinates.

Based on immediate follow-up and longitudinal data, where available, the following picture emerged for the trainee group as a whole:

\begin{tabular}{lcc} 
& $\begin{array}{c}\% \text { Improvement } \\
\text { six months after } \\
\text { programme }\end{array}$ & $\begin{array}{c}\text { o lmprovement } \\
\text { programme }\end{array}$ \\
Self-sufficiency & 31 & 37 \\
Attitude & 17 & 19 \\
Creativity and problem & & 43 \\
$\quad$ solving & 32 & 37 \\
Decision-making & 23 & 44 \\
Time keeping & 24 & 39 \\
Work accuracy & 15 & 51 \\
Work rate & 22 & 39 \\
Productivity & 20 & 41 \\
Handling of interper- & 14 & 43 \\
$\quad$ sonal relationships & 17 & - \\
Control of subordinates & & \\
\hline
\end{tabular}

Naturally there were substantial differences from organization to organization and group to group with an approximate 70 who showed no or negative improvement (retrogression).

However, the figures make it more than apparent that the trend is substantially forward, and in the direction of the kind of behaviour required from supervisory/managerial personnel.

Furthermore, the impact seems to be lasting and escalatory - providing the corporate climate is supportive of the new behaviours acquired and demonstrated by the $n$ Ach trainees. The most notable follow-up research in this regard is that reported by $\mathrm{Nel}$ (1983).

Regarding the career progress of this group some $69 \%$ of the participants were promoted within their organizations. When compared with the matched control groups in 26 of the organizations, this promotion index was significant at the $5 \%$ level.

Of the promoted group

$57 \%$ - moved up 1 position in the organizational ladder, $21 \%$ - moved up 2 positions,

$18 \%$ - moved up 3 positions,

$4 \%$ - moved up 4 and/or more positions, during the period June 1979 - December 1983.

This movement is regarded as very substantial by any standard, particularly when one takes into account that $72 \%$ of the promotions were for Black participants. It can therefore be stated in definite terms that the programme has not only produced an improved employee behaviour but furthermore assisted in causing some $69 \%$ of the participants on this Achievement Training programme to climb the corporate ladder towards the supervisory and managerial ranks.

\section{A critique of the present programme}

Although by any training and development standards the results have been substantial, there is much room for improvement in the design and hence operating efficiency of the programme.

There has been a real need for the re-evaluation of the course content, and this research is being completed at the time of this article going to press. The major emphasis is on improving the impact of the newly learned skills into on-the-job behaviour, particularly in relation to the individual motivation for acquiring more and better skills.

To this end the following re-structuring of the course elements is suggested:

(a) Understanding motivation,

(b) Orientation to achievement motivation,

(c) Planning process,

(d) Leadership,

(e) Communication,

(f) Problem analysis and problem solving,

(g) Handling and developing subordinates,

(h) Managing interpersonal relations,

(i) Teamwork,

(j) Managing change and resistance to change,

(k) Productivity,

(l) The Pygmalion effect.

Of particular significance has been the discovery that the training of Mentors for the mentoring process will considerably enhance the impact of Achievement Training in terms of organizational health - via communication and goodwill and pure output. Much attention is presently being given to the value of this specific aspect in the training process.

Finally let it be noted that this training process is organic in nature and therefore can only be successful in such organizational climates as support and enhance its basic philosophy - i.e., selected employees can be taught to become more achievement-oriented and this will lead to more positive attitudes and improved job behaviour. This can only happen if the newly acquired enthusiasm and behaviour are encouraged and rewarded by specific managerial recognition for improved performance.

\section{Conclusion:}

This research has attempted to provide a possible solution to 
help alleviate the critical shortage of supervisory/managerial skills in Southern Africa.

From the overview of the results it is apparent that the Achievement Training process has achieved two objectives: (a) it considerably enhances on-the-job behaviour as assessed by the immediate line manager; and

(b) it has assisted in causing upward mobility for $69 \%$ of the programme participants, - many of whom have been moved into supervisory or managerial positions.

That the training process is organic and needs therefore to be constantly reviewed cannot be denied. Already substantial research has been completed into making this training process even more dynamic by aiding the growth of both the managerial skills and the economic wealth of Southern Africa.

\section{References}

Atkinson, J.W. \& Feather, N.T. 1966. The theory of achievement motivation. New York: John Wiley.

Herzberg. F. 1968. One more time: How do you motivate employees? Harv. Bus. Rev. Jan-Feb.

Hofmeyr, K.B. 1982. The formulation of a model for the development of potential Black Managers in South Africa. Pretoria: University of South Africa, School of Business Leadership. (Unpublished DBL thesis).

Human Sciences Research Council, 1979. The demand for and supply of Manpower: Part II. Pretoria: HSRC.

Kolb, D.A., Rubin, I.M. \& McINtyre, J.M. 1978. Organizational Psychology - An experiential approach. 3rd edition. Englewood Cliffs: Prentice-Hall.

McClelland, D.C. 1958. The achievement motive. New York: D. van Nostrand.
McClelland, D.C. 1961. The achieving society. New York: D. van Nostrand.

McClelland, D.C. 1962. Business Drive and National Achievement. Harv. Bus. Rev. $99-111$.

McClelland, D.C. \& Steele, R.S. 1973. Human morivaton: a book of readings. Morristown, New Jersey: General Learning Press.

McClelland, D.C., Atkinson, J.W., Clark, R.S. \& Lowell, E.L. 1975. The achievement motive. New York: Irvington Publishers.

Nasser, M.E., Motsepe, Q. \& Lenamile, D. 1980. A profile of black accountants. Unpublished report for the Transvaal society of chartered accountants.

Nasser, M.E. \& Buitendag, J. 1984. Mentoring - the key to accelerated manager development. S.A. Training - 1984 Yearbook.

Nel, J. 1983. Teaching people to become achievers. Management, June.

Rosen, J. 1961. The management of individual growth through the need for achievement. In: McClelland, D. The achieving society. new York: Van Nostrand.

Sadie, J. 1979., in Financial Mail editorial. November.

Sorcher, M. \& Goldstein, A. 1971. Changing supervisory behaviour. New York: Pergammon Press.

Skinner, B.F. 1972. Beyond freedom and dignity. New York: Knops.

Tabane, A. 1979. The socio-cultural background of the black South African and its impact on business development. Pretoria: Position paper.

Thopane, S. 1982. The evaluation of a training programme to stimulate a need for achievement in black employees. Pretoria: UNISA, SBL. (Unpublished MBL thesis).

University of South Africa, 1980. The manpower analysis for the PWV area to the period 1984. Pretoria: UNISA, SBL.

Willers, C.J. 1983. An evaluation of achievement training. Johannesburg: University of the Witwatersrand. (Unpublished MBA thesis).

Winter, D.G. 1973. The power motive. London: Collier-MacMillan.

Zaleznik, A. 1977. Power and the corporate mind. New York: Knops. 